\title{
Estimation of soil hydraulic parameters for different land-uses
}

\author{
Fereshte Haghighi Fashi $^{1} \cdot$ Manouchehr Gorji $^{1} \cdot$ Mahdi Shorafa $^{1}$
}

Received: 12 September 2016/Accepted: 27 September 2016/Published online: 3 October 2016

(c) Springer International Publishing Switzerland 2016

\begin{abstract}
Water retention capacity and saturated hydraulic conductivity are important soil hydraulic properties that affect soil productivity and the environment. The knowledge of soil water properties and land-use effects on these properties are important for efficient soil and water management. The aim of this work was to evaluate the effect of cultivation of rangelands on soil water retention. Furthermore, the use of the van Genuchten equation to estimate soil saturated water content $\left(\theta_{s}\right)$ and water content $\left(\theta_{h}\right)$ was assessed. The comparison of the parameters of this equation [water release parameters ( $\alpha$ and $n$ ) and residual water content $\left(\theta_{r}\right)$ ] obtained in cultivated and rangelands was also evaluated. Moreover, a comparison between measured and estimated soil saturated hydraulic conductivity $\left(K_{s}\right)$ by several selected pedotransfer functions (PTFs) was performed. The study showed that the land-use effect on soil water retention was significant only at water potentials of -33 and $0 \mathrm{kPa}$ in the top $15 \mathrm{~cm}$ of the soil. At the $-1500 \mathrm{kPa}$ pressure head, water content was not affected by the land-use type at soil depths of $0-15 \mathrm{~cm}$ and $15-30 \mathrm{~cm}$. In this study, $\alpha, n$, and $\theta_{r}$ values were not significantly different between the two land-use types. The fit of the van Genuchten model to water retention data resulted in a low sum of squared errors and high coefficient determination values. Overall, the van Genuchten equation can be used as a physically based model for soil water retention characterization in the studied area. However, this model was not able to accurately estimate $K_{s}$. No distinct trend for estimated $K_{s}$ by the selected PTFs in the studied
\end{abstract}

Fereshte Haghighi Fashi

Haghighif634@yahoo.com

1 Soil Science and Engineering Department, University of Tehran, Tehran, Iran area was observed. Thus, it is essential to evaluate the model applicability for different soils at various sites.

Keywords Land use - Soil hydraulic properties · Van Genuchten equation - Water retention

\section{Introduction}

Soil hydraulic properties are important to understand the transmission properties and water balance in soils (Hillel 1998). The characterization of the hydrological behavior of catchments requires a knowledge of hydraulic parameters (Santra and Das 2008). One important soil hydraulic property is water retention capacity, which affects soil productivity and management. Soil water content $\left(\theta_{h}\right)$ governs the transport characteristics of water and solutes in soils. The knowledge of water retention capacity and landuse effects on this property is important for efficient soil and water management. Upon conversion of natural lands to cultivated fields, water retention capacity is strongly influenced (Schwartz et al. 2000; Bormann and Klaassen 2008; Zhou et al. 2008). Soil water retention at field capacity (FC) and permanent wilting point $(P W P)$ are important to estimate the irrigation water depth, which may be affected by land-use change. Understanding the relation between water storage capacity and land-use change is important in determining the flow properties of water in soil. Several researchers have demonstrated that land-use type has an important effect on the soil hydraulic characteristics (Sonneveld et al. 2003; Bodhinayake and Cheng Si 2004; Bormann and Klaassen 2008). The characteristic of soil water retention is affected by soil organic carbon (SOC) content and porosity, which are significantly influenced by land-use type (Zhou et al. 2008). Soil water 
retention and saturated hydraulic conductivity $\left(K_{s}\right)$ are necessary input data for the simulations of water flow in soil and water engineering. Land-use changes in a given soil result in a change of soil properties and inputs for PTFs. Field measurements and simulation models can be used to describe soil water retention (Schwartz et al. 2000; Sonneveld et al. 2003).

The determination of soil water properties required as input data for simulation models is time consuming and relatively costly (Wösten et al. 1995). Thus, indirect estimation of these characteristics has been proposed as one alternative to direct estimation of the soil hydraulic parameters based on the measured water retention data. To estimate the land-use effects on soil water retention, the van Genuchten model (Van Genuchten 1980) may be applied. Schwartz et al. (2000) showed that the simultaneous fit of the Mualem-van Genuchten equation (Van Genuchten 1980) to water retention data resulted in a good fit for different land uses. Sonneveld et al. (2003) also used the Mualem-van Genuchten equation for fitting $\theta_{h}$ data for the retention curves in different land uses. Evett et al. (1999) fitted the $\theta_{h}$ data to the Mualem-van Genuchten equation using RETC software (retention curve) (van Genuchten et al. 1991) and obtained acceptable results $\left(r^{2} \geq 99\right)$. Porebska et al. (2006) showed that there are correlations between soil physical properties and van Genuchten parameters. Several researchers have correlated van Genuchten parameters with soil organic matter (SOM), bulk density (BD), and soil particle size distribution (Sonneveld et al. 2003), and many researchers have estimated the water retention curve using soil texture, bulk density, and porosity (Nemes and Rawls 2004; Timlin et al. 2004). For instance, Guber et al. (2004) assumed that van Genuhten parameters ( $\alpha$ and $n$ ) relate to the small and large aggregate contents in the soil, respectively. Estimation of the van Genuchten parameters, $\alpha$ and $n$, using the RETC program can be used to develop models to estimate these parameters using basic soil properties (Kutula and Ersahin 2008). Continuous pedotransfer functions (PTFs), which estimate van Genuchten parameters using some soil properties (i.e., BD and SOC), can be considered as suitable tools for the characterization of water retention (Van Alphen et al. 2001).

Many statistical equations (pedotransfer functions) characterizing the water retention curve have been presented (Kutilek and Nielsen 1994). PTFs are useful tools for modeling applications. Such analytical functions are derived involving various soil data that are measured in the field and from laboratory analyses. Soil hydraulic parameters derived through PTFs can be used to express soil hydraulic properties and water retention (Brooks and Corey 1964). Consequently, physically based models, such as the van Genuchten model representing a pedotransfer function, may be considered as valuable tools to simulate the soil water properties in different land uses. Investigations on soil hydraulic properties affected by land use are not comprehensive when compared to studies on soil chemical properties. As a result, land-use types result in changes of soil organic matter and bulk density, thus, leading to a different input for PTFs in a given soil (Sonneveld et al. 2003). Despite its importance, there is a lack of understanding of suitable PTF applications and documentations of PTF applications in dryland farming and rangeland in the Taleghan watershed in Iran.

The objectives of this work were as follows: (1) to evaluate, document, and quantify the effect of cultivation of natural lands on soil water retention in field capacity (FC) and permanent wilting point (PWP) moisture points, (2) to test the use of the van Genuchten equation to estimate $\theta_{h}$ and to evaluate the prediction accuracy of $K_{s}$, (3) to compare the van Genuchten model parameters $[\alpha, n$, and residual water content $\left(\theta_{r}\right)$ ] obtained in cultivated and rangelands, and (4) to compare the measured $K_{s}$ with that estimated $K_{s}$ by selected PTFs in the same soils of the Taleghan watershed in Iran.

\section{Materials and methods}

This study was conducted on soil in the Taleghan watershed in Iran, which was covered by rangeland and dryland farming (converted more than 50 years ago). The site $\left(36^{\circ} 08^{\prime} 58^{\prime \prime} \mathrm{N}\right.$ and $\left.50^{\circ} 43^{\prime} 12^{\prime \prime} \mathrm{E}\right)$ had an elevation of $1453 \mathrm{~m}$ with homogeneous soils. According to a Taleghan watershed study report (University of Tehran 1993), the studied soils were calcareous and classified as Typic Xerorthents. The soil had a pH (in $\mathrm{M} \mathrm{KCl}$ ) of 7.8-7.9, and the electrical conductivity (EC) of the soils varied from 0.47 to $0.56 \mathrm{dS}$ $\mathrm{m}^{-1}$ at depths of $0-15 \mathrm{~cm}$ and $15-30 \mathrm{~cm}$, respectively. The land slope was approximately $15 \%$. The minimal and maximal daily temperatures were approximately -5.6 and $17{ }^{\circ} \mathrm{C}$, respectively. The mean annual rainfall varied from 464 to $796 \mathrm{~mm}$. The dominant rangeland plant species were Astrangalus alopecuriodes and Sophora alopecuriodes, which were converted into cultivated wheat, and the soil texture was clay loam. The overall soil BD and $\theta_{h}$ were determined by 72 undisturbed steel cores that were $100 \mathrm{~cm}^{3}$ (volume) by $5 \mathrm{~cm}$ (diameter) with four replicates taken from depths of $0-15 \mathrm{~cm}$ and $15-30 \mathrm{~cm}$. The core method was used to measure soil bulk density (Blake and Hartge 1986), and the soil saturated hydraulic conductivity $\left(K_{s}\right)$ was measured using a constant head method (Klute and Dirksen 1986). Twenty four composite soil samples were air-dried and passed through a $2-\mathrm{mm}$ sieve. The particle size distribution was determined using a hydrometer method (Gee and Bouder 1986), and the OM content 
was determined using a wet oxidation method previously described by Walkley and Black (1934). The $\theta_{h}$ and water potential $(\Psi)$ data was obtained from laboratory measurements. $\theta_{(h)}$ was determined at various potentials $(0,-33$, $-50,-100,-500,-1000$, and $-1500 \mathrm{kPa}$ ) by a pressure chamber apparatus with four replicates (Klute 1986). The $\theta_{(h)}$ data were fit to the van Genuchten equation to derive retention curves and parameters $\left(\alpha, n\right.$, and $\left.\theta_{r}\right)$ for two landuse types using the RETC (retention curve) optimization computer code (Van Genuchten et al. 1991). Parametric estimation was used in this study. The van Genuchten model is defined as follows:

$\theta(h)=\theta_{r}+\frac{\theta_{s}-\theta_{r}}{\left(1+|\alpha h|^{n}\right)^{m}} \quad \theta_{(h)}=\theta_{s} \quad \mathrm{~h} \geq 0$

where $\theta_{(h)}\left(\mathrm{cm}^{3} \mathrm{~cm}^{-3}\right)$ is the volumetric water content (for $\mathrm{h}<0) ; \theta_{r}\left(\mathrm{~cm}^{3} \mathrm{~cm}^{-3}\right)$ is the residual water content; $\theta_{s}\left(\mathrm{~cm}^{3}\right.$ $\left.\mathrm{cm}^{-3}\right)$ is the saturated water content; $m$ is $1-(1 / n)$ with $n>1$; and $\alpha\left(\mathrm{cm}^{-1}\right)$ and $n$ are empirical parameters determining the shape of the curve, which were obtained for each core. Parameter $n$ is related to steepness of the water retention curve.

$K\left(S_{e}\right)=K_{s} S_{e}\left[1-\left(1-S_{e}^{(1 / m)}\right)^{m}\right]$

where $K_{s}(\mathrm{~mm} / \mathrm{h})$ is saturated hydraulic conductivity and $S_{e}$ is the effective saturation expressed as follows:

$S_{e}=\frac{\theta-\theta_{r}}{\theta_{s}-\theta_{r}}$

The equations previously described by Mishra and Parker (1990), van Genuchten (1980), and Wösten (1997) were used to estimate the saturated hydraulic conductivity $\left(K_{s}\right)$ in this study.

The equation described by Mishra and Parker (1990) is as follows:

$K_{s}\left(\mathrm{~mm} \mathrm{~s}^{-1}\right)=1080\left(\theta_{s}-\theta_{r}\right)^{2.5} \alpha^{2}$

where $K_{s}$ is the soil saturated hydraulic conductivity $\left(\mathrm{mm} \mathrm{s}^{-1}\right)$.

Wösten (1997) has defined the transformed parameter $K_{s}$ model as follows:

$$
\begin{aligned}
K_{s}^{*}= & 9.5-1.47(\mathrm{D})^{2}-0.688(O M)+0.0369(O M)^{2} \\
& -0.332 \ln (C S)
\end{aligned}
$$

where $K_{s}^{*}, D, O M$, and $C S$ are the transferred saturated hydraulic conductivity, bulk density, organic matter, and percentage of clay and silt, respectively.

\section{Statistical analysis}

A significant test on the land use was performed using the analysis of variance (ANOVA) within the general linear model (GLM) of SAS software (1999). The model performance was evaluated using measured soil water retention data, simulated soil water retention data, sum of squares errors (SSE), SD, and $R^{2}$.

\section{Results and discussion}

Table 1 presents several soil properties for depths of 0-15 cm and 15-30 cm corresponding to two land-use types. Significant differences in the OM and BD were observed between dryland farming and rangeland at both depths (Table 1). Soil sample water contents at different pressure heads under both land-use types are presented in Fig. 1. The overall measured and fitted soil water retention curves did not show significant difference within the selected water potentials for both land-use types in this study. However, measured $\theta_{s}(0 \mathrm{kPa})$ values were found to be significantly lower (by 11.7 and $11.1 \%$ ) for dryland farming when compared with rangeland at depths of 0-15 cm and 15-30 cm, respectively. Moreover, the landuse effect on soil water retention was significant at a water potential of $-33 \mathrm{kPa}$ (FC) based on laboratory measurements only at the top (15 cm depth) (Fig. 2). The results indicated that the conversion of rangeland to dryland farming led to a significant decrease (16.56\% on average) in the FC at a depth of $0-15 \mathrm{~cm}$. The mean $-1500 \mathrm{kPa}$ $(P W P)$ water content was not affected by the land-use type. Figure 2 indicates that the mean total field capacity (FC) was significantly greater in rangeland when compared with dryland farming at a depth of 0-15 cm. In this study, there were not statistically significant differences in water content at other potentials $(-50,-100,-500$, and $-1000 \mathrm{kPa}$ pressures) between the two types of land use presented in Fig. 1. At those pressure heads and at a $-1500 \mathrm{kPa}$ water content, the amount of micropores were not affected by the land-use type. Despite the strong relationship between the SOM and water retention capacity, the water content at low pressure heads was not affected by land-use change or decrease of the SOM in dryland farming, which may be due to a stronger effect of the SOM on FC than the effect of the SOM on water retention at $-1500 \mathrm{kPa}$ (Rawls et al. 2003). Overall, the results show that the soil pore system and reduced total porosity under dryland farming can decrease water storage capacity at water potentials of -33 and $0 \mathrm{kPa}$. A previous study has shown that improper soil management decreases the soil macroporosity in the longterm affecting the $\theta_{s}$ (Ndiaye et al. 2007). Higher porosity of rangeland soils when compared with cropland soils and higher saturated water content in pasture soils when compared with dryland farming soils were found by Sonneveld et al. (2003). The result of the current investigation agrees 
Table 1 General soil properties for the two selected land-use types

\begin{tabular}{|c|c|c|c|c|c|c|}
\hline \multirow[t]{2}{*}{ Land use } & \multirow[t]{2}{*}{ Depth $(\mathrm{cm})$} & \multicolumn{3}{|c|}{ Soil particle size distribution (\%) } & \multirow[t]{2}{*}{$\mathrm{BD}^{* *}$} & \multirow[t]{2}{*}{$\% \mathrm{SOM}^{*}$} \\
\hline & & Sand & Silt & Clay & & \\
\hline \multirow[t]{2}{*}{ Rangeland } & $0-15$ & 24.6 & 46.5 & 28.9 & $1.19^{\mathrm{c}}$ & $2.20^{\mathrm{a}}$ \\
\hline & $15-30$ & 24.7 & 43.1 & 32.2 & $1.21^{\mathrm{bc}}$ & $1.91^{\mathrm{ab}}$ \\
\hline \multirow[t]{2}{*}{ Dryland farming } & $0-15$ & 31.6 & 39.1 & 29.2 & $1.34^{\mathrm{b}}$ & $1.67^{\mathrm{bc}}$ \\
\hline & $15-30$ & 29.4 & 38.1 & 32.5 & $1.53^{\mathrm{a}}$ & $1.42^{\mathrm{c}}$ \\
\hline
\end{tabular}

The values of BD and SOM that share the same letters (a-d) are not significantly different at $p<0.05$

* Soil organic matter

** Bulk density
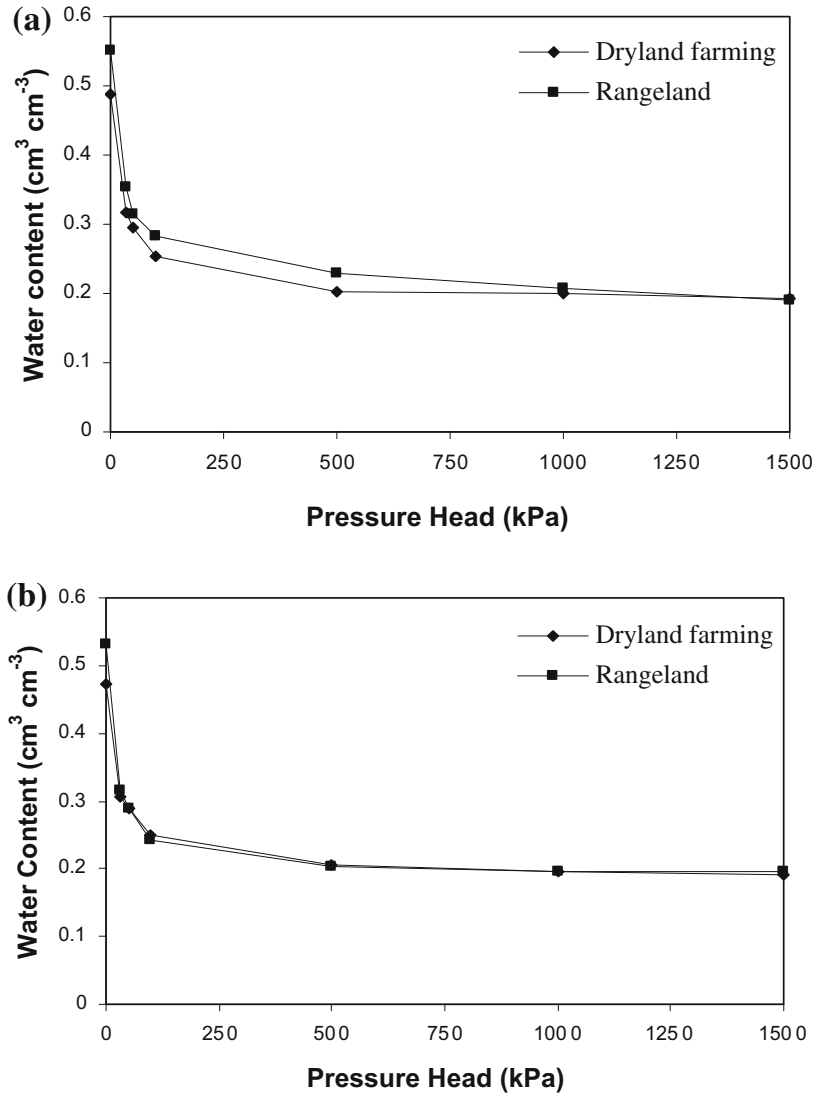

Fig. 1 Soil water content as a function of the pressure head for two land-use types at depths of a $0-15 \mathrm{~cm}$ and $\mathbf{b} 15-30 \mathrm{~cm}$

with a previous study by Buytaert et al. (2005) who demonstrated that the $-1500 \mathrm{kPa}$ water content and water retention at low potentials in cultivated soils are not significantly lower than those of natural lands. As a result, the lower BD and higher SOM in the rangeland soils have likely led to higher soil water retention at the -33 and $0 \mathrm{kPa}$ potentials affecting water retention properties. The relationship between an alteration in the SOM and porosity can lead to higher $-33 \mathrm{kPa}$ water content in rangeland soils (Rawls et al. 2003; Buytaert et al. 2005). The data obtained in this study demonstrated the loosening effect of dryland farming on soil water retention. Previous studies
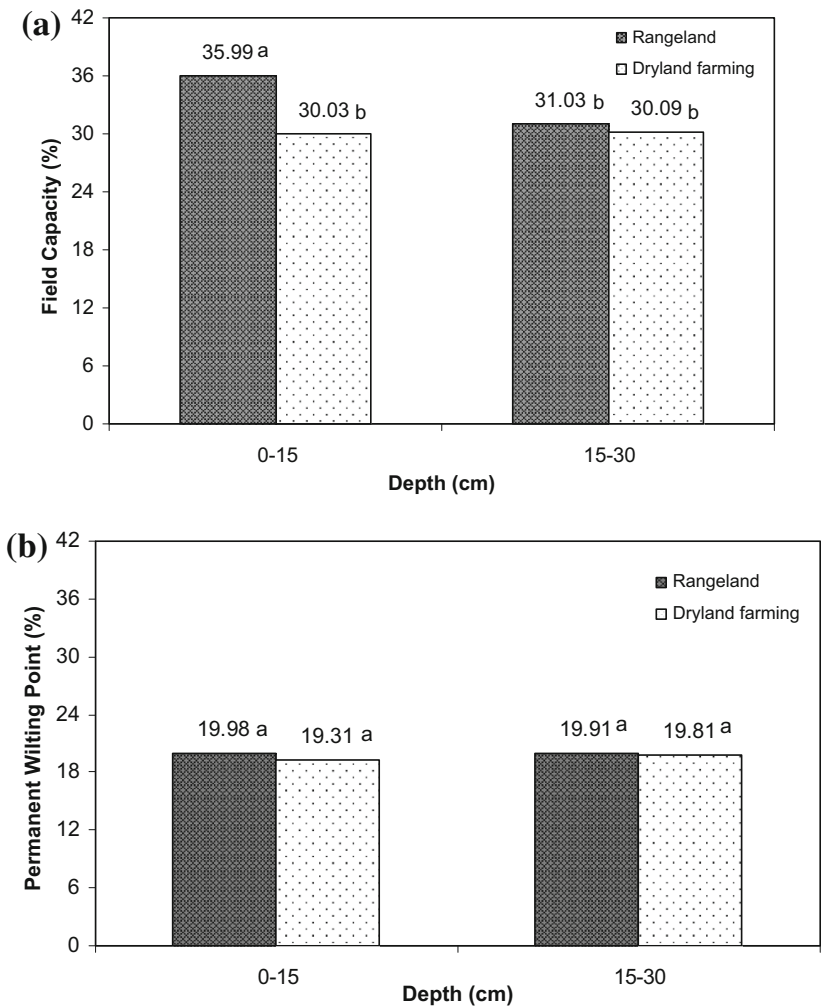

Fig. 2 Effect of land-use change on a soil field capacity (FC) and b permanent wilting point (PWP) of two the land-use types (contents of FC and PWP that share the same letters $(a-c)$ are not significantly different at $\mathrm{p}<0.05$ )

on the effect of land use have demonstrated clear changes in soil physical properties, such as soil porosity, SOM, and $\mathrm{BD}$, in relation to hydraulic properties (Celik 2005; Bormann and Klaassen 2008; Haghighi et al. 2010b), which agrees with the results obtained in the present study.

\section{Modeling performance}

Fitted parameter values and standard errors obtained from the simultaneous fit of the $\theta_{h}$ data to Eq. (1) are presented in Table 2. The fit of the van Genuchten model to water 
Table 2 Estimated mean values of van Genuchten parameters

\begin{tabular}{|c|c|c|c|c|c|c|c|c|}
\hline \multirow[t]{2}{*}{ Land use } & \multicolumn{4}{|c|}{ Depth: $0-15 \mathrm{~cm}$} & \multicolumn{4}{|c|}{ Depth: $15-30 \mathrm{~cm}$} \\
\hline & $n$ & $\alpha$ & $\theta_{r}$ & $\theta_{s}$ & $n$ & $\alpha$ & $\theta_{r}$ & $\theta_{s}$ \\
\hline Dryland farming & 1.5817 & 0.0106 & 0.1754 & 0.4874 & 1.5056 & 0.0129 & 0.1691 & 0.4724 \\
\hline SSE & 0.09738 & 0.00226 & 0.00852 & 0.0039 & 0.0762 & 0.0026 & 0.0084 & 0.0029 \\
\hline Rangeland & 1.3443 & 0.0206 & 0.1387 & 0.5523 & 1.7780 & 0.0096 & 0.1861 & 0.5314 \\
\hline SSE & 0.14127 & 0.01230 & 0.04467 & 0.00737 & 0.08794 & 0.00139 & 0.00419 & 0.0033 \\
\hline
\end{tabular}

$n$ empirical parameter, $\alpha$ empirical parameter $\left(\mathrm{cm}^{-1}\right), \theta_{r}$ residual water content $\left(\mathrm{cm}^{3} \mathrm{~cm}^{-3}\right), S S E$ sum of squares errors, $\theta_{s}$ soil saturated water content $\left(\mathrm{cm}^{3} \mathrm{~cm}^{-3}\right)$ retention data resulted in a low SSE and high $R^{2}$. The SSE values indicated the deviation of estimated values from the observed values (Table 2). In the case of the Taleghan watershed soils, the van Genuchten model resulted in satisfactory estimates of water retention capacity except in saturated water content $\left(\theta_{s}\right)$. Model simulations using the van Genuchten model strongly corresponded with laboratory soil water retention measurements. The overall fit of the van Genuchten model to water retention data resulted in low SSE and high $R^{2}$ values (0.98-0.99) for clay loam soils from the studied area with both land-use types. Similar results were obtained by Schwartz et al. (2000) and Evett et al. (1999) who found that the $\theta_{h}$ data fit to the van Genuchten equation yields acceptable results (high $R^{2}$ ). The modeling performance was similar for both land uses and depths. Comparing the estimated $\theta_{r}, n$, and $\alpha$ values with the van Genuchten equation did not show significant differences between the two land-use types (at $\mathrm{p}<0.05$ ). The $n$ parameters for rangeland were 0.0206 and 0.009 at depths of $0-15 \mathrm{~cm}$ and $15-30 \mathrm{~cm}$, respectively, and these values were not significantly different from the dryland farming $n$ parameters, which were 0.106 and 0.129 for depths at $0-15 \mathrm{~cm}$ and $15-30 \mathrm{~cm}$, respectively. These parameters were not significantly different between the cultivated lands and rangelands. $\Theta_{r}$ is the water content at the lowest soil water potential $(-1584.9 \mathrm{kPa})$ (Ndiaye et al. 2007). Thus, at this pressure head and $P W P$ water content, the water is retained in soil micropores, which is not affected by land-use type. As reported by Ndiaye et al. (2007), the $n$ parameter is influenced by soil texture, which is related to soil particle size distribution. This parameter can be changed with alteration of soil, sand, silt, and clay particles (Porebska et al. 2006). Therefore, the $n$ parameter is not influenced by land-use change. Because $\alpha$ and $n$ are empirical parameters determining the shape of the water retention curve (Sonneveld et al. 2003), it was concluded that there was no significant differences between the retention curves of dryland farming and rangeland. This conclusion was apparently related to insignificant differences in water retention data at the considered pressure heads, which may be attributed to the insignificant effect of land-use on micropores. This observation was revealed by comparing the shape of the curves presented in Fig. 1. Comparing the shape of water retention curves can be an indicator of hydraulic properties, which were similar for low pressure heads in this study. Schwartz et al. (2000) obtained satisfactory estimates of water retention using the Mualem-van Genuchten model except at a near saturation water content, which was similar to what was obtained in this study.

Figure 3 shows the relationship between the measured and estimated $K_{s}$ by three types of PTFs. The van Genuchten model was not able to estimate the $K_{s}$, and the estimated values of this parameter were the same for the studied soils in the selected area with both land-use types. Moreover, significant differences were observed between the measured and estimated $K_{s}$ by the point pedotransfer
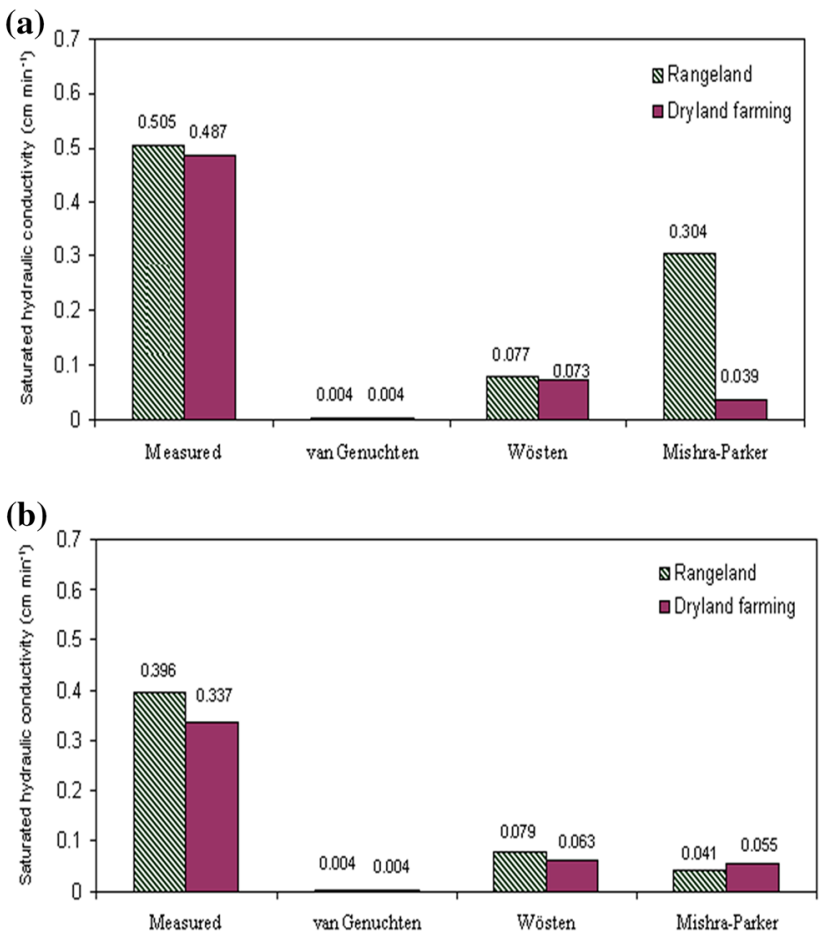

Fig. 3 Comparing measured and estimated saturated hydraulic conductivity by van Genuchten, Wösten, and Mishra-Parker pedotransfer functions at two land-use types at the depths of a $0-15 \mathrm{~cm}$ and $\mathbf{b} 15-30 \mathrm{~cm}$ 
functions as described by Wösten (1997) and Mishra and Parker (1990), which may be attributed to the difference in texture and bulk density ranges than those used to develop PTFs applied in this study. Furthermore, complicated conditions in the laboratory (disturbed core samples producing preferential flow) may be other probable reasons for the observed difference between measured and estimated $K_{s}$ by PTFs. The use of PTFs as an empirical relationship must be limited by the range or type of soils from the data used to drive them (Wösten et al. 2001). The PTFs developed on soils similar to those in the studied area may perform better when compared to other soils (Givi et al. 2004; Haghighi et al. 2010a). A good estimated saturated hydraulic conductivity is obtained when pore sizes have been measured in addition to the typical PTF inputs (soil texture, BD, and OM). Thus, selecting appropriate PTFs is a crucial task for applications in regions where developed PTFs are not available because of the lack of large databases.

\section{Conclusions}

Results of this study suggest that soil management and land-use change affect SOM content and soil water retention only at a $-33 \mathrm{kPa}$ (FC) potential in the top $15 \mathrm{~cm}$ of soil based on laboratory measurements and model simulations. Additional research is essential to evaluate the SOM effect on the water retention capacity at different low pressure heads (e.g., $-1500 \mathrm{kPa}$ ) for dryland farming. The results of this study showed that higher water content at the $-33 \mathrm{kPa}$ potential would be expected upon conversion of natural lands to cultivated lands. In addition, the saturated soil water content $\left(\theta_{s}\right)$ was affected by the land-use change. Moreover, because cultivation of natural lands affects soil macroporosity, we suggest measuring soil water retention at higher suction heads to document the land-use effect on soil water retention properties in relation to soil macropores. Evaluation of the land-use effect on soil water properties is needed not only to document the changes but also for the ability to manage and govern the effects that land-use type has on these properties.

The fit of the van Genuchten model to the water retention data resulted in a low SSE and high $R^{2}$. This finding showed that the van Genuchten model was useful in describing soil water retention in clay loam soils in the studied area. Thus, use of this model should be considered as a valuable tool to gain more knowledge of hydraulic properties for various soil types. Point PTFs of soil saturated hydraulic conductivity could not be used in this case study. The effect of land-use type on soil water retention and PTF applications have not been documented in the studied area to the best of our knowledge. In Iran, there is a lack of large databases that are needed to develop PTFs. Thus, in many developing countries, such as Iran, the use of available PTFs can cause errors for estimating soil hydraulic properties. The results of this study encourage further investigations of the model applications and development of suitable point and parametric PTFs for estimating soil hydraulic properties in the studied area. The selection of more suitable PTFs for application where there are not developed PTFs caused by a lack of large databases is difficult. Consequently, it is essential to evaluate the model applicability and to develop point and parametric PTFs for estimating soil hydraulic properties for the soils and land uses in this study and various other sites. Thus, the estimates may be improved by comprehensive local studies.

\section{References}

Blake GR, Hartge KH (1986) Bulk density. Methods of soil analysis. Part 1. Physical and mineralogical Methods. In: Klute A (ed) Agronomy monographs, vol 9, 2nd edn. ASA-SSA, Madison, WI, pp 363-375

Bodhinayake W, Cheng Si B (2004) Near-saturated surface soil hydraulic properties under different land uses in the St. Denis National Wildlife Area. Hydrol Process 18:2835-2850

Bormann H, Klaassen K (2008) Seasonal and land use dependent variability of soil hydraulic and soil hydrological properties of two Northern German soils. Geoderma 145:295-302

Brooks RH, Corey AT (1964) Hydraulic properties of porous media. Civil Engineering Department, Colorado State University, Fort Collins, $\mathrm{CO}$

Buytaert W, Wyseure G, De Bievre B, Deckers J (2005) The effect of land use changes on the hydrological behaviour of Histic Andosols in south Ecuador. Hydrol Process 19:3985-3997

Celik I (2005) Land use effects on organic matter and physical properties of soil in a southern Mediterranean highland of Turkey. Soil Tillage Res J 83:270-277

Evett SR, Peters FH, Jones OR, Unger PW (1999) Soil hydraulic and retention curves from tension infiltrometer and laboratory data. In: Van Genuchten MTh, Leij FJ, Wu L (eds) Proc. Int. Workshop Characterization and measurement of the Hydraulic Properties of Unsaturated Porous Media. University of California, Riverside, pp 541-551

Gee GW, Bouder JW (1986) Particle size analysis. Methods Soil Anal A Geogr 27:47-60

Givi J, Prasher SO, Patel RM (2004) Evaluation of pedotransfer functions in predicting the soil water contents at field capacity and wilting point. J Agric Water Manag 70:83-96

Guber A, Pachepsky Y, Shein E, Rawls WJ (2004) Soil aggregates and water retention. In: Pachepsky Y, Rawls WJ (eds) Development of pedotransfer functions in soil hydrology. Elsevier, Amsterdam, London, NewYork, Tokyo

Haghighi F, Gorji M, Shorafa M, Sarmadian F, Mohammadi MH (2010a) Evaluation of some infiltration models and hydraulic parameters. Span J Agric Res (INIA) 8(1):210-217

Haghighi F, Gorji M, Shorafa M (2010b) A study of the effects of land use change on soil physical properties and organic matter. Land Degrad Dev J. doi:10.1002/ldr.999 (in press)

Hillel D (1998) Environmental soil physics. Academic Press Inc., New York 
Klute A (1986) Water retention: laboratory methods. In: Klute A (ed) Methods of Soil Analysis. Part 1. Physical and Mineralogical Methods, 2nd edn. American Society of Agronomy, Soil Sci. Soc. Am J, Madison, WI, pp 635-662

Klute A, Dirksen C (1986) Hydraulic conductivity and diffusivity. In: Klute A (ed) Methods of soil analysis. Part 1. Physical and mineralogical Methods, Agronomy monographs, 2nd edn. ASASSA, Madison, WI, pp 687-734

Kutilek M, Nielsen DR (1994) Soil Hydrology. Catena Verlag, Cremlingen, Destedt, pp 1-333

Kutula T, Ersahin S (2008) Calibration of Van Genuchten unsaturated hydraulic conductivity parameters by regression technique. In: Proc. International Meeting on Soil Fertility Land Management and Agroclimatology. Turkey, pp 175-181

Mishra S, Parker JC (1990) On the relationship between saturated conductivity and capillary retention characteristics. Ground Water 28:775-777

Ndiaye B, Molenat J, Hallaire V, Hamon CGY (2007) Effects of agricultural practices on hydraulic properties and water movement in soils in Brittany (France). Soil Tillage Res J 93:251-263

Nemes A, Rawls WJ (2004) Soil texture and particle-size distribution as input to estimate soil hydraulic properties. In: Pachepsky Y, Rawls WJ (eds) Development of Pedotransfer Functions in Soil Hydrology. Elsevier, Amsterdam

Porebska D, Slawinski C, Lamorski K, Walczak RT (2006) Relationship between van Genuchten's parameters of the retention curve equation and physical properties of soil solid phase. Int Agrophys 20:153-159

Rawls WJ, Pachepsky YA, Ritchie JC, Sobecki TM, Bloodworth H (2003) Effect of soil organic carbon on soil water retention. Geoderma 116:61-76

Santra P, Das BS (2008) Pedotransfer functions for soil hydraulic properties developed from a hilly watershed of Eastern India. Geoderma 146:439-448

SAS (1999) SAS user's guide: Statistics Release 8.0. SAS Inst., Cary, $\mathrm{NC}$

Schwartz RC, Unger PW, Evett SR (2000) Land use effects on soil hydraulic properties. ISTRO

Schwartz RC, Evett SR, Unger PW (2003) Soil hydraulic properties of cropland compared with reestablished and native grassland. Geoderma 116(1-2):47-60
Sonneveld MPW, Bachx MAHM, Bouma J (2003) Simulation of soil water regimes including pedotransfer functions and land use related preferential flow. Geoderma 112:97-110

Timlin DJ, Williams RD, Ahuja LR, Heathman GC (2004) Simple parametric methods to estimate soil water retention and hydraulic conductivity. In: Pachepsky Y, Rawls WJ (eds) Development of pedotransfer functions in soil hydrology. Elsevier, Amsterdam, London, New York, Tokyo

University of Tehran (1993) Taleghan Watershed study report. Irrigation Engineering Department, Iran

Van Alphen BJ, Booltink HW, Bouma J (2001) Combining pedotransfer functions with physical measurements to improve the estimation of soil hydraulic properties. Geoderma 103:133-147

Van Genuchten MTh (1980) A closed-form equation for predicting the hydraulic conductivity of unsaturated soils. Soil Sci Soc Am J 44:892-898

Van Genuchten MTh, Leij FJ, Yates SR (1991) The RETC code for quantifying the hydraulic functions of unsaturated soils. EPA/ 600/2-91/065. In: Kerr RS (ed) Environmental Research Laboratory. US Environmental Protection Agency, Ada, OK, p 83

Walkley A, Black CA (1934) An examination of the Degtjareff method of determining soil organic matter and a proposed modification of the chronic acid titration method. Soil Sci 37:29-38

Wösten JHM (1997) Pedotransfer functions to evaluate soil quality. In: Gregorich EG, Carter MR (eds) Soil quality for crop production and ecosystem health. Developments in Soil Science, Elsevier, Amsterdam, pp 221-245

Wösten JHM, Finke PA, Jansen MJW (1995) Comparison of class and continuous pedotransfer functions to generate soil hydraulic characteristics. Geoderma 66:227-237

Wösten JHM, Pachepsky YA, Rawls WJ (2001) Pedotransfer functions: bridging the gap between available basic soil data and missing soil hydraulic characteristics. J Hydrol 251:123-150

Zhou X, Lin HS, White EA (2008) Surface soil hydraulic properties in four soil series under different land uses and their temporal changes. Catena 73:180-188 